NASA/TM-1999-208901

AIAA-99-0370

\title{
NASA/FAA Tailplane Icing Program Overview
}

Thomas P. Ratvasky

Lewis Research Center, Cleveland, Ohio

Judith Foss Van Zante

Dynacs Engineering Co., Inc., Brook Park, Ohio

James T. Riley

FAA Technical Center, Atlantic City Airport, New Jersey

Prepared for the

37th Aerospace Sciences Meeting \& Exhibit

sponsored by the American Institute of Aeronautics and Astronautics

Reno, Nevada, January 11-14, 1999

National Aeronautics and

Space Administration

Lewis Research Center 


\section{Acknowledgments}

The authors would like to thank the technical staffs from the NASA Icing Research Tunnel, OSU Low Speed Wind Tunnel, and the NASA Twin Otter. Special recognition goes to Mr. Richard Ranaudo for both his superb skills as a test pilot and his keen research insight, and to Dr. Dale Hiltner for all of his effort in developing TAILSIM. We

thank Mr. John P. Dow, Sr., of the FAA Small Airplane Directorate, for his continued support and active promotion of the TIP. We also would like to express our appreciation to our sponsors, NASA's Aviation Operations Systems Base program and the FAA Technical Center.

Trade names or manufacturers' names tre used in this report for identification only. This usage does rot constitute an official endorsement, either expressed or im plied, by the National

Aeronautics and Space Ad ninistration.

Available from

NASA Center for Aerospace Information 800 Elkridge Landing Road

Linthicum Heights, MD 21090-2934

Price Code: A03
National Technical Information Service 5287 Port Royal Road Springfield, VA 22100

Price Code: A03 


\title{
NASA/FAA TAILPLANE ICING PROGRAM OVERVIEW
}

\author{
Thomas P. Ratvasky \\ Aerospace Engineer \\ NASA Lewis Research Center \\ Cleveland, $\mathrm{OH} 44135$ \\ Judith Foss Van Zante \\ Member, AIAA \\ Senior Engineer \\ Dynacs Engineering Co., Inc. \\ Brook Park. OH 44142 \\ James T. Riley \\ FAA Technical Center \\ Atlantic City Airport, NJ 08405
}

\begin{abstract}
The effects of tailplane icing were investigated in a four-year NASA/FAA Tailplane Icing Program (TIP). This research program was developed to improve the understanding of iced tailplane aeroperformance and aircraft aerodynamics. and to develop design and training aides to help reduce the number of incidents and accidents caused by tailplane icing. To do this, the TIP was constructed with elements that included icing wind tunnel testing, dry-air aerodynamic wind tunnel testing, flight tests, and analytical code development. This paper provides an overview of the entire program demonstrating the interconnectivity of the program elements and reports on current accomplishments.
\end{abstract}

\section{List of Symbols and Abbreviations}

$\begin{array}{ll}\text { S\&C } & \text { stability and control } \\ C_{d} & \text { drag coefficient } \\ C_{l} & \text { lift coefficient } \\ C_{m} & \text { pitching-moment coefficient } \\ C_{\mathrm{He}} & \text { elevator hinge-moment coefficient } \\ \mathrm{C}_{\mathrm{T}} & \text { thrust coefficient } \\ \mathrm{G} & \text { acceleration due to gravity } \\ \mathrm{cg} & \text { aircraft center of gravity } \\ \mathrm{V}_{\mathrm{fe}} & \text { flap extension speed } \\ \mathrm{V}_{\mathrm{s}} & \text { stall speed }\end{array}$

\section{Greek:}

$\alpha \quad$ angle-of-attack, deg

$\alpha_{\text {aail }} \quad$ tail angle-of-attack, deg

$\alpha_{\mathrm{J}_{\mathrm{C}}} \quad$ aircraft angle-of-attack, deg

$\beta \quad$ angle-of-sideslip. deg

$\delta e, d E$ elevator deflection, deg

$\delta \mathrm{F}, \mathrm{dF}$ flap deflection angle, deg

\section{Introduction}

Ice impedes the productivity and safe utililization of all aircraft. As a result, substantial efforts have been undertaken to reduce the safety risks associated with aircraft icing. Although considerable progress has been made in icing research and engineering, some aircraft designs are still susceptible to certain ice-related problems, one being ice contaminated tailplane stall (ICTS).

Tailplane stall due to icing is not a new problem. Aircraft incidents and accidents have occurred sporadically since the late 1950 's. At that time, the cause of these incidents and accidents was unknown. But now, it is clear that these events were related through loss of pitch stability and control probably due to ice on the horizontal tail. Aircraft accident analyses have revealed ice contamination on horizontal tailplanes as the primary cause of over 16 accidents resulting in 139 fatalities.

The ICTS events usually occurred on final approach, when flaps were extended. Ice on the horizontal tail caused premature flow separation. The separated flow could not attain pressure recovery over the elevator and resulted in stick force reversal (control column pulled away from the pilot). The aircraft would pitch nose down and rapidly lose altitude (Figure 1).

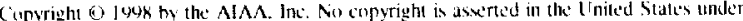

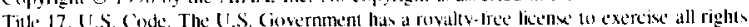
under the copyright claimed herein for Giwvernmertit purpeses. All other rights are ne'served hy the conyright owser. 
Generally, the aircraft could be recovered only by retracting the flaps and by the sheer strength of the pilots pulling back on the control column.

Although tailplane stall due to icing can occur on any class of airplane, the problem has had the highest rate of occurrence on the commuter and light transport airplanes. Various reasons are offered to explain this. (1) Commuters operate for greater periods of time within potential ice zone altitudes than do the large transports and therefore have a greater likelihood of encountering icing. (2) Ice protection systems on commuters are typically de-icers, which may lead to reduced airfoil performance due to residual ice and ice buildup between deicing cycles.

Previous research efforts to understand tailplane icing were conducted hy a Swedish-Soviet working group during the 1970 's to $1980{ }^{\prime} \mathrm{s}^{23}$. The first report described an experimental study of icing on the aerodynamics of high-lift. swept-wing sections. Experimental methods were developed to estimate "critical" ice shapes, to simulate icing conditions, and to fabricate ice "imitators". The second and third reports focused on tailplane icing and its effects on longitudinal stability and control. Wind tunnel and flight tests were conducted to study the tailplane stall phenomenon. This research effort provided excellent insights into some of the aspects of ice contaminated tailplane stall.

The icing research program at NASA LeRC also studied the stability and control changes due to tail ice on a DHC-6 Twin Otter aircraft ${ }^{5}$. Results showed the longitudinal stability decreased significantly with artificial ice on the horizontal tail, and that the stability was further decreased with the flaps deflected to $10^{\circ}$. High thrust coefficient and low aircraft-angle-of-attack were also significant contributors to the reduced stability. In addition, elevator control effectiveness was significantly reduced with the artificial ice.

To promote awareness of the tailplane icing problem, the Federal Aviation Administration (FAA) sponsored three International Tailplane Icing Workshops in November 1991, April 1993, and September 1994. These workshops generated approximately 30 recommendations addressing issues on the icing environment, aerodynamics, ice detection and protection systems, flight operations. and maintenance. In response to some of these recommendations, the FAA requested that NASA conduct research into the characteristics of ICTS and to develop techniques and methodologies to minimize the hazard. A specific request was made to improve the understanding of the dynamic and aerodynamic characteristics of the socalled pushover and sideslip flight maneuvers, and to develop a hody of knowledge and theory behind the critical degradation of longitudinal stability and control caused by tailplane icing. NASA responded to the FAA request by developing the NASA/FAA Tailplane Icing Progranı (TIP). The TIP was co-sponsored by NASA LeRC and the FAA Technical Center through an Interagency Agreement.

The purpose of this paper is to provide an overview of the entire Tailplane Icing Program and illustrate the interconnectivity of the program elements. It also summar:zes the current results from each element.

\section{NA SA/FAA Tailplane Icing Program History}

In early 1994, representatives from NASA LeRC, the FAA Technical Center, FAA Certification Service, and the Ohio State University met to discuss potential program activities described in a NASA-developed work plan ${ }^{6}$. The primary results from these planning meetings were:

1. the confirmation of the NASA/FAA Tailplane Icing Program with funding from both NASA LeRC and the FAA Technical Center,

2. the establishment of a cooperative agreement between NASA and the Ohio State University, and

3 . concurrence between the various parties on the tasks to be accomplished in the program.

In :rder to expand the understanding of iced tailplane aeroperformance. icing wind tunnel testing and aerodyna.mic (dry air) wind tunnel testing of a tailplane model were determined necessary. Flight testing was also necessary to verify wind tunnel results and evaluate the maneuvers of interest to the FAA and other parties. Finally, it was desired to have an analytical method for discriminating tailplane sensitivity that would use results from the wind tunnel and flight tests for developt tent and evaluation. These ideas formed the foundation of the program.

The TIP became a four-year research program that utilized c combination of icing experts and test facilities that included NASA Lewis' Icing Research Tunnel (IRT), The Ohio State University (OSU) Low Speed Wind Tunnel (LWST), and NASA Lewis' DeHavilland DHC-6 Twin Otter Icing Research Aircraft. These resource: were used to accomplish the following program goals:

1. Impoove understanding of iced tailplane aeroperformance and aircraft aerodynamics,

2. Develop analytical tools to help assess tailplane sensitivity to icing, and

3. Develop training aides to expand the awareness of the ICTS aviation hazard 


\section{Model Selection}

The first step in the program was to select an appropriate model to test. A DHC-6 Twin Otter tailplane was chosen as the subject of the study because:

- The DHC-6 had a known susceptibility to ICTS

- NASA-LeRC owned a DHC-6with a full compliment of flight dynamic and cloud physics instrumentation

- NASA LeRC had 12 years of experience with the DHC-6 flight characteristics in icing, reflected in extensive documentation and a databank of performance, stability and control derivatives with and without icing on the aircraft

Since wind tunnel testing was to be conducted at the NASA IRT that has a $6^{\prime} \times 9^{\prime}$ test section and the OSU LSWT that has a 7' $x 10^{\prime}$ test section, it was opted to obtain two models, one for each tunnel. The characteristics of each model are described in the following paragraphs.

The model used in the IRT was made from an actual Twin Otter tailplane (Figure 2). The flight hardware was cut to provide a 6-foot span, 2D model for IRT testing. A new BFGoodrich pneumatic boot with standard coverage for a Twin Otter was installed on the leading edge to determine inter-cycle ice accretions. Load cells were incorporated with the elevator hinge brackets to be able to measure the elevator hinge moment throughout the testing.

The model used in the OSU LSWT was made from a material called Ren Shape ${ }^{(B)} 450$ (machineable plastic). The 2D model was made to be full-scale 4.75-foot chord, and 7-foot span (Figure 3). The model was designed to replicate the two-section geometry of the Twin Otter and had an elevator that could be set to discrete angles for testing elevator effects. The model incorporated approximately 90 chordwise pressure taps in a mid-span location for acquiring data on the aeroperformance. A pressure belt, similar to the one used in flight. was also used to correlate with the pressure tap data. Likewise, a 5-hole probe, similar to those used in the flight tests was mounted for comparison purposes.

\section{Ice Shape Selection}

The second step was to develop ice shapes for testing. Developing accurate ice shapes for this program was very important, so an IRT entry was scheduled. Due to scheduler constraints at the IRT, testing was not possible in the early phase of the program, so it was decided to perform initial aeroperformance tests at OSU on two other ice shapes. The first ice shape was used in previous stability and control projects and was therefore labeled S\&C Ice (Figure 4). The shape was determined using a method described in Reference 7, and the icing flight conditions and photographs from one of NASA LeRC's 1984 icing flights. The second shape tested was predicted by LEWICE version 1.3 (Figure 5). The conditions used to derive the LEWICE shape were:

- $V=120$ knots, $\alpha=0^{\circ}$

- $\mathrm{LWC}=0.5 \mathrm{~g} / \mathrm{m}^{3}, \mathrm{MVD}=20 \mu \mathrm{m}$

- $\mathrm{T}_{0}=-4^{\circ} \mathrm{C}$, time $=45$ minutes

Both the S\&C and LEWICE shapes were fabricated for wind tunnel testing using Ren Shape ${ }^{\otimes}$ and were strictly 2D. After machining. the fabricated shapes were sanded smooth and painted. No attempt was made to vary the shape in span or simulate ice roughness with grit material.

Two other ice shapes were selected for aeroperformance testing. These shapes were the result of the IRT test. (More details on the IRT test are found in the next section). One shape represented ice accretion remaining on the tail between the pneumatic de-ice boot operation - Inter-cycle Ice (Figure 6). Another shape represented the ice accretion during a failed de-ice boot condition - Failed Boot Ice (Figure 7). The icing conditions used to form these ice shapes were the same with the exception of the time. These conditions were:

- $\quad \mathrm{V}=135$ knots, alpha $=-2.9^{\circ}$

- $\mathrm{LWC}=0.5 \mathrm{~g} / \mathrm{m}^{3}, \mathrm{MVD}=20 \mu \mathrm{m}$

- $\mathrm{T}_{0}=-4^{\circ} \mathrm{C}$,

- time $=22$ minutes for Failed Boot Ice

- time $=15$ minutes, with boot cycle every 3 minutes up to 12 minutes for Inter-cycle Ice

After the ice accretion was formed on the model, molds were made of approximately a 15-inch span of the ice on the model. New methods were employed to extract multiple polyurethane castings from the molds to have full-span ice accretion in the aeroperformance wind tunnel test and flight test (described in later sections).

\section{Icing Wind Tunnel Test}

The icing wind tunnel test was conducted in February 1996 at the NASA LeRC Icing Research Tunnel. The IR'T is a closed-loop, refrigerated wind tunnel (Figure 8). The temperature is controllable from $40^{\circ} \mathrm{F}$ to $-40^{\circ} \mathrm{F}$. A water spray system has been calibrated to simulate icing clouds with droplet MVD of $14-40 \mu \mathrm{m}$. and liquid water content (LWC) of 0.2 to $3.4 \mathrm{~g} / \mathrm{m}^{3}$. The test section is 6-feet high by 9-feet wide, and a 5,000 hp motor drives a fan to provide test section speeds up to $400 \mathrm{mph}$ (empty test section). A turntable in the floor 
provides angle of attack changes to models mounted vertically.

The Twin Otter tailplane model was mounted vertically and attached to the IRT force-balance system on the turntable and tunnel ceiling. Approximately 30 test points were made varying icing cloud conditions and temperatures, deicer boot-cycle time, spray time, airspeed, angle of attack and elevator deflection to simulate cruise, holding, and approach phases of flight. After each icing condition, the model was rotated from $+4^{\circ}$ to $-22^{\circ} \mathrm{AOA}$ while recording force-balance and hinge moment data with the ice accretion. Afterwards, ice tracings and photo documentation were made of the ice shape. At the end of each night, a mold was made of the final ice accretion. The primary results from the IRT entry were the ice castings described in the previous section and viewed in Figure 6 and Figure 7. These castings were utilized in both the aeroperformance wind tunnel and flight test studies.

\section{Aeroperformance Wind Tunnel Tests}

Initial aeroperformance testing was conducted during September 1994 at the OSU 7'x 10' LSWT (Figure 9). The LSWT is a closed loop tunnel with a 2,000 hp electric motor to provide dynamic pressures up to 65 psf in the 7 ' $\times 10^{\prime}$ section. A turntable in the floor allows vertically mounted airfoil models to be tested between $-90^{\circ}$ to $270^{\circ}$ angle of attack. The Twin Otter tailplane model was tested with a no-ice (baseline) and with the $S \& C$ and LEWICE fabricated ice configurations. The test matrix included 2 airspeeds, 6 elevator angles, and 10-13 angles of attack for 2 airfoil section geometries.

Surface pressure tap and drag wake survey data were acquired to calculate the $C_{l}, C_{d}, C_{m}$ and $C_{H e}$ for each configuration and test condition. The results from this test are reported in Ref 8 .

A second phase of testing was conducted during August 1996 at the OSU LSWT using the ice castings developed from the IRT test. Similar to the 1994 test, measurements of the surface pressures and wake drag survey were used to calculate the aeroperformance coefficients. The results from this test ane reported in Ref 9.

A sample of the aero wind tunnel results for one elevator deflection ( $\delta e=0^{\circ}$ ) can be seen in Figure 10-Figure 13. All aeroperformance coefficients $\left(C_{l}, C_{d}, C_{m}\right.$ and $\left.C_{H e}\right)$ are affected by the ice contamination to some degree. Ranking the ice shapes in terms of lift coefficient, the least affected was the inter-cycle ice, followed by the failed boot ice, and ending with both the S\&C and LEWICE ice shapes having the most degradation in $\mathrm{C}_{\mathrm{lmax}}$ and reduction in stalling ingle of attack. The reductions in $\mathrm{C}_{\mathrm{m} \text { max }}$ and stalling angle of attack for each shape are listed in Table 1.

Table 1 Reductions in $\mathrm{C}_{\text {Imax }} \& \alpha_{\text {stall }}$

\begin{tabular}{|l|c|c|}
\hline Ice Shape & $\Delta \mathbf{C}_{\mathbf{l m a x}}(\%)$ & $\Delta \boldsymbol{\alpha}_{\text {stall }}\left({ }^{\circ}\right)$ \\
\hline Inter-cycle & 30 & 2.3 \\
\hline Failed Boot & 41 & 7.3 \\
\hline S\&C & 50 & 9.5 \\
\hline LEWICE & 50 & 9.5 \\
\hline
\end{tabular}

Similarly, there was an increase in drag coefficient with each ice shape. The LEWICE shape had the greatest increase in drag overall. The pitching moment coefficient followed a similar trend to the lift coefficient. All shapes caused an early departure to a positive pitching moment, but the LEWICE and S\&C shapes caused this to happen at the least negative alpha. The hinge moment coefficient had sone unusual characteristics with two of the ice shapes. With the S\&C and LEWICE shapes, the $\mathrm{C}_{\mathrm{He}}$ behavior was as expected. Premature separation caused a rapid increase in the $\mathrm{C}_{\mathrm{He}}$, which is typically attributed to the "yoke snatch" experienced by pilots during a tailplane stall. But for both ice castings, the $\mathrm{C}_{\mathrm{He}}$ was initially reduced below the baseline and then followed the expecter trend of a rapid increase in $\mathrm{C}_{\mathrm{He}}$ as the angle of attack became more negative. One possible explanation for this behavior may be the very rough texture and 3D nature of the ice castings. These irregular protrusions may have acted as vortex generators, which energized the boundary layer and reduced the hinge moment for the lower angles of attack. However, as the angle of attack was further increased, the separation bubble extended far enough down the chord to cause the hinge moment shift as was seen in the other two ice shape cases. This phenomt non may be airfoil specific and was not explored further because it was not central to the program tasks.

Similar data was collected for each elevator setting, airspeed and airfoil section. These results were directly used in the analytical code development and flight test planning tasks. This work was fundamental to the continuation of the project and provided valuable informat ion to reduce risk during the flight tests.

\section{Flight Tests}

Flight $t \geq s t s$ were conducted with the NASA Icing Research Aircraft. The aircraft is a modified DHC-6 Twin Oter that has been used extensively at NASA LeRC for over 16 years to acquire natural icing flight 
data as well as explore the icing effects on aircraft performance, stability and control. For the TIP, the aircraft was equipped with instrumentation to sense and record the following:

- inertial parameters (linear acceleration, angular rates and position)

- air data (airspeed, angle of attack, sideslip, outside air temperature, pressure altitude),

- engine data (propeller RPM, engine torque pressure, fuel flow)

- control surface deflections (elevator, ailerons, rudder, flap)

- pilot forces (elevator, aileron, rudder)

- video of pilot action \& horizon

Due to the nature of this testing, new instrumentation was added to record tailplane specific data:

- tailplane flow field \& surface pressures.

- tailplane flow visualization

Three 5-hole probes were mounted along the span of the left horizontal tail's leading edge to record the flow field at the tailplane (Figure 14). A pressure belt was wrapped around the stabilizer and elevator to allow calculation of the tailplane lift performance. A video camera was mounted below the tail to monitor and record tuft activity on the suction surface.

\section{Phase 1 Baseline Tests}

Initial baseline (clean tail) flight tests were conducted September to October 1995. The purpose of these flights were to:

- confirm DHC-6 hydraulic system functionality during low-G pushovers

- determine tail flow conditions and elevator settings for cruise, hold, and approach flight phases which were used in the IRT tests

- determine range of tailplane inflow angles for all flap, speed, thrust and normal accelerations to be tested with the ice shapes

In this first phase, 17 flights were made to document baseline tailplane aerodynamics in steady and maneuvering flight. Control variables were thrust coefficient $\left(C_{T}\right)$, flap deflection $(\delta F)$, airspeed $(V)$, angle of attack $(\alpha)$, angle of sideslip $(\beta)$, pitch rate $(q)$ and normal acceleration $\left(\mathrm{N}_{2}\right)$. Data was recorded for all maneuvers listed in Table 2.

\section{Table 2 Baseline Flight Test Maneuvers (Phase 1)}

\begin{tabular}{|l|c|}
\hline Maneuver & Number of test points \\
\hline Take off \& Landing & 20 \\
\hline I-G Steady wings level & 377 \\
\hline Steady heading sideslip & 233 \\
\hline Pushover & 419 \\
\hline Trim point recovery & 20 \\
\hline Stall recovery & 24 \\
\hline Wind-up turns & 2 \\
\hline
\end{tabular}

The steady wings level and steady heading sideslip test points were 1-G unaccelerated steady test points and are self-explanitory. The pushover was a longitudinal-axis maneuver to reduce normal acceleration to zero-G by the pilot performing a series of nose-up and nose-down control inputs. Figure 15 provides a graphical representation of a pushover to zero-G. The trim point recovery was similar to the pushover, but the nose-down push on the control column was limited to the column position where trim was established. Stall recovery maneuvers were initiated from a near-stall speed where a nose-down control column was implemented to recover from the stall. Wind-up turns were performed through steep-turns to reach 2-G normal acceleration.

The results from this initial effort were used directly in the IRT test and analytical code development, and provided critical information needed to proceed to the next phase of flight test with the ice shapes.

\section{Phase 2 Inter-cycle Ice Tests}

The second phase of flight tests was conducted on the Twin Otter between July and October 1997. After repeating selected baseline tests, the inter-cycle ice castings were mounted to the horizontal tail (Figure 16Figure 17). Flight tests points included 1-G steady wings level, steady heading sideslips, thrust transitions, pushovers, and elevator doublets. These maneuvers were conducted for the full range of flap settings $[0,10$, $20,30, \& 40]$ and airspeeds $\left[\mathrm{V}_{\mathrm{s}}\right.$ to $\left.\mathrm{V}_{\mathrm{fe}}\right]$. Note: The DHC-6 is placarded to warn pilots not to extend the flaps greater than $10^{\circ}$ in icing conditions. This flight test was executed in a highly structured research environment in order to capture a full compliment of aircraft configurations. NASA LeRC subscribes to the $10^{\circ}$ flap limitation in routine icing operations and does not recommend exceeding the manufacturers stated limitations. Table 3 provides a summary of the maneuvers flown with the inter-cycle ice shape.

Table 3 Inter-cycle Ice Flight Test Maneuvers

\begin{tabular}{|l|c|}
\hline Maneuver & Number of test points \\
\hline 1-G Steady wings level & 67 \\
\hline Steady heading sideslip & 15 \\
\hline Pushover & 32 \\
\hline Thrust Transition & 29 \\
\hline Elevator Doublet & 16 \\
\hline
\end{tabular}

Flow unsteadiness on the lower side of the tail was detected through minor yarn tuft activity in the $1-G$ steady wings level points when flaps were extended to $\delta \mathrm{F}=30 \& 40^{\circ}$. During the pushover and elevator doublets, flow separation occurred when flaps were extended to $\delta \mathrm{F}=20^{\circ}$ or more. It was during the intercycle ice configuration that the thrust transition 
maneuver was developed. It was found that by holding velocity constant and slowly increasing the thrust, that at some level of thrust. flow separation and tail stall could be initiated. Moreover, the elevator was deflected trailing edge up (TEU), which was a common tailplane configuration for landing. (Note that for the pushover, the elevator was deflected trailing edge down at minimum $\alpha_{1}$ ). Thrust transitions were included in the test matrix for the remaining cases. Elevator doublets, typically used for system identification and parameter estimation flight tests, were also added to the test matrix. The elevator doublet consisted of four step inputs to the elevator initiated from straight and level flight. Parameter estimation analysis and examination of the damping characteristics was possible with the elevator doublets.

\section{Phase 2 Failed Boot lce Tests}

After fully testing the inter-cycle ice shape, the failed boot ice shape was mounted on the tailplane (Figure 18) and flight tests proceeded to explore the boundaries of tail stall with this level of ice contamination. Maneuvers similar to the inter-cycle ice were flown, and are listed in Table 4

Table 4 Failed Boot Ice Flight Test Maneuvers

\begin{tabular}{|l|c|}
\hline Maneuver & Number of test points \\
\hline l-G Steady wings level & 64 \\
\hline Steady heading sideslip & 12 \\
\hline Pushover & 29 \\
\hline Thrust Transition & 23 \\
\hline Elevator Doublet & 17 \\
\hline Wind up turns & 9 \\
\hline Flap transitions & 2 \\
\hline
\end{tabular}

As expected from the wind tunnel results, there was greater aeroperformance degradation with the failed boot ice shape than the inter-cycle shape. The full test matrix was not completed because the boundary of tailplane stall with this ice shape was found during the thrust transition maneuver with $\delta \mathrm{F}=40^{\circ}$. During this maneuver, a full tail stall occurred when the thrust reached approximately $\mathrm{C}_{\mathrm{T}}=0.13$ (nominal cruise power) at an indicated airspeed of VIAS $=85$ knots. The stall caused the aircraft to pitch nose-down for $3-\sec$ to $\theta=-$ $37^{\circ}$ and lose 300 feet of altitude even though recovery procedures were employed within $1 / 4$ second of the stall. After this test point, the pushovers were limited to $\delta \mathrm{F}=20^{\circ}$ and elevator doublets were limited to a maximum $\delta \mathrm{F}=30^{\circ}$.

\section{Phase 2 S\&C Ice Tests}

The final ice shape tested was the $\mathrm{S} \& \mathrm{C}$ shape (Figure 19). As the wind tunnel tests indicated, the aeroperformance characteristics for this ice shape were the worst and nearly identical to the LEWICE shape. For this reason, the LEWICE shape was not flight tested. Table 5 lists the details of this limited test matrix.

Table 5 S\&C Ice Flight Test Maneuvers

\begin{tabular}{|l|c|}
\hline Maneuver & Number of test points \\
\hline 1-G Steady wings level & 62 \\
\hline Steady heading sideslip & 12 \\
\hline Pushover & 27 \\
\hline Thrust Transition & 26 \\
\hline Elevator Doublet & 24 \\
\hline
\end{tabular}

Duc: to stability and control problems with the $S \& C$ ice, maximum flap deflection was limited to 30 degrees for the steady points, the elevator doublets and power transition points. The maximum flap deflection for the pushover was limited to 20 degrees. Even with these limitations, flow separation and control force reversals were experienced many times during these tests.

\section{Flight Test Result Summary}

Results from these flight tests are being published in References $10,11 \& 12$. Three of the key flight test accomplishments were (1) the identification of the dominart drivers that led to ICTS (termed "Paths to Tailplane Stall"), (2) the recognition of tactile cues of an impending tail stall, and (3) the development and demonstration of an effective tail stall recovery procedure. These accomplishments are outlined below.

The paths to tailplane stall on the test aircraft were:

- Increased Ice Shape Severity

- Increased Flap Deflection

- Increased Speed

- Increased Thrust (may be airplane specific)

The increase in ice shape severity (based on wind tunnel tests) reduced the stalling angle of attack $\left(\alpha_{\text {tail }}\right)$ and $\mathrm{C}_{\text {lmax }}$ of tailplane, so that ICTS was encountered at premature test conditions $\left(\delta \mathrm{F}, \mathrm{N}_{\mathrm{z}}, \alpha_{\mathrm{a} / \mathrm{c}}\right.$ ). As the flaps were deflected, the $\alpha_{\text {ail }}$ was made more negative due to an increase in wing downwash and a decrease in $\alpha_{a / c}$ to maintain aircraft lift coefficient. As the speed increased, the $\alpha_{\text {ail }}$ was made more negative due to a decrease in $\alpha_{a / c}$. Firally, as thrust was increased, a greater tail downloaj was required to counteract the nose-down pitching moment because the thrust line was above the $\mathrm{cg}$. For some configurations, the tail $\mathrm{C}_{1}$ required may exceed the $C_{1}$ available and result in a ICTS event.

Tactile cues that preceded the tail stall events were an inability or difficulty to trim, pitch excursions, onset of pilot nduced oscillations, buffeting in the controls not the a rframe.

When the full tail stall was experienced during the power $\operatorname{tr}$ insition, the stall recovery procedure was:

- Reduce thrust (may be airplane specific) 
- Pull back on yoke / increase $\alpha$

- Raise flaps

Reducing thrust was the first part of the procedure because it was increasing thrust that led to the stall event that was encountered. Pulling hack on the yoke increased the camber of the tailplane, which provided enough tail download to counteract the nose-down pitching moment and increase the $\alpha_{\text {tail }}$. Raising the flaps was initiated by the copilot immediately, but the flaps are hydraulically actuated and movement is rather slow $(\sim 1 \% \mathrm{sec})$. The major lesson learned to recover from a tail stall was to undo what was just done to cause the event.

It was noted that this tail stall recovery procedure is opposite of the recovery from a wing stall. The reason for the difference is the location of the flow separation. In a wing stall, the flow separates from the upper surface of the wing, therefore reattachment is made by decreasing the wing $\alpha$. In a tail stall event, the flow separates from the lower surface of the tail and requires a positive increase in tail $\alpha$ to reattach the flow. Because of these differences in the stalling mechanisms and recovery procedures, it was determined that pilots should be made aware of the cues that may occur prior to a tailplane stall. Efforts to increase pilot awareness on this topic are described in the following section.

\section{Guest Pilot Workshop \& Tailplane Icing Video}

At the conclusion of the flight tests, it was felt the TIP gathered enough new information that it needed to be quickly shared. A Guest Pilot Workshop was developed to demonstrate the unique flying qualities of an aircraft with an ice-contaminated tailplane. An international group representing various facets of the aviation industry - aviation regulatory agencies, aircraft manufacturers and aviation media pilots/reporters were invited. In total, 15 guest pilots and engineers had the opportunity to fly the NASA Twin Otter. This demonstration program provided a mutually beneficial forum for the exchange of information between NASA and the user community. Feedback from the guest pilots was very positive. Each indicated a greater appreciation of ICTS as a result of this guest pilot workshop. Media articles were written in the winter of 1997-98 to provide a rapid dissemination of some of the key lessons learned to the pilot community.

Further dissemination of vital information was accomplished through the production and distribution of a 23-minute educational video entitled, "Tailplane Icing". The target audience is primarily pilots who might encounter in-flight icing. The video has been enthusiastically received, and is available upon request through the authors.

\section{Analytical Tool}

The third element of the TIP was the development of an analytical tool to help assess an aircraft susceptibility to ice contaminated tailplane stall. The tool was a flight path simulation code based on a 6-degree of freedom, non-linear model. The computer code, TAILSIM, was constructed using a database of stability and control derivatives obtained from flight tests [Ref 5], wind tunnel results [Ref 8,9], and standard methods for estimating aircraft/tailplane parameters, downwash angles, and tailplane dynamic pressure ratios. The result was a new database that combined the aeroperformance effects of the ice contamination measured in the OSU tunnel with the flight dynamics of the Twin Otter. The simulation estimated the flow field at the tail, determined the lift, drag, pitching moment, elevator hinge moment, and the resulting motion of the aircraft. Test maneuvers were "flown" and the response characteristics were noted in terms of tailplane angle of attack, pitch stability, and control-force reversal. Comparisons to flight test data were made with acceptable results (Figure 20). This work was accomplished as part of a Ph.D. dissertation and is fully explained in Ref 13.

\section{Conclusions}

The NASA/FAA Tailplane Icing Program was a fouryear research program that utilized a combination of icing experts and test facilities that included NASA Lewis' Icing Research Tunnel (IRT), The Ohio State University (OSU) Low Speed Wind Tunnel, and NASA Lewis' DeHavilland DHC-6 Twin Otter Icing Research Aircraft. These resources were used in combination to accomplish the following program goals:

1. improve understanding of iced tailplane aeroperformance and aircraft aerodynamics.

2. develop analytical tools to help discriminate tailplane sensitivity to icing, and

3. develop training aides to expand the awareness of the ICTS aviation hazard

The interconnectivity of the program elements led to the safe and successful outcome of reaching the program goals. Insights gained through this program were the paths to stall, recognition of tactile cues prior to an impending tail stall, and a demonstrated recovery procedure. The rapid dissemination of key information to pilots was accomplished through the guest pilot workshop, the media articles, and the "Tailplane Icing" video. All of these serve as good examples of NASA"s response to flight safety initiatives and the quick release of information to the user community. 


\section{Acknowledgments}

The authors would like to thank the technical staffs from the NASA Icing Research Tunnel, OSU Low Speed Wind Tunnel, and the NASA Twin Otter. Special recognition goes to $\mathrm{Mr}$. Richard Ranaudo for both his superb skills as a test pilot and his keen research insight, and to Dr. Dale Hiltner for all of his effort in developing TAILSIM. We thank Mr. John P. Dow, Sr., of the FAA Small Airplane Directorate, for his continued support and active promotion of the TIP. We also would like to express our appreciation to our sponsors, NASA's Aviation Operations Systems Base program and the FAA Technical Center.

\section{References}

I Dow, J.P. Sr.. FAA Small Airplane Directorate, private communication

2 Ingelman-Sundherg, M. \& Trunov, O.K., "Methods For Prediction Of The Influence Of Ice On Aircraft Flying Characteristics," Swedish-Soviet Working Group on Flight Safety Report No. JR-1. 1977

3 Ingelman-Sundberg, M. \& Trunov, O.K., "Wind Tunnel Investigation Of The Hazardous Tail Stall Due To lcing." Swedish-Soviet Working Group on Flight Safety Report No. JR-2. 1979

4 Trunov, O.K. \& Ingelman-Sundberg, M., "On The Problem Of Horizontal Tail Stall Due To Ice," Swedish-Soviet Working Group on Flight Safety Report No. JR-3. 1985

5 Ratvasky, T.P. \& Ranaudo, R.J., "Icing Effects on Aircraft Stability and Control Determined from Flight Data, Preliminary Results," AIAA-93-0398, NASA TM 105977, 1993

6 Ratvasky. T. P., “NASA/FAA Tailplane Icing Program Work Plan," April 1994

7 Bowen, D.T., Gensemer, A.E., Skeen, C.A., "Engineering Summary of Airframe Icing Technical Data." General Dynamics/Convair, San Diego, CA, Technical Report ADS-4, 1964

8 Hiltner, D.W., McKee, M., La Noé, K.B., "DHC-6 Twin Otter Tailplane Airfoil Section Testing in The Ohio State University 7x10 Wind Tunnel," 1995. being reviewed for publication

9 Gregorek, G.M., Dreese, J.J., La Noé, K.B., "Additional Testing of the DHC-6 Twin Otter Iced Airfoil Section at The Ohio State University $7 \times 10^{\prime}$ Wind Tunnel." 1996, being reviewed for publication
10 Ratvasky, T.P., Van Zante, J. Foss \& Sim, A.G. "NASA/FAA Tailplane Icing Program: Flight Test Report," being reviewed for NASA/FAA TP

11 Ratvasky, T.P. \& Van Zante, J. Foss, "In-flight Aerodynamic Measurement of an Iced Tailplane," AIA A 99-0638, 1999

12 Van Zante, J. Foss \& Ratvasky, T.P.. "Investigation of Dynamic Flight Maneuvers with an Iced Tailplane," AIAA 99-0371, 1999

13 Hiltrer, D. W., "An Investigation of the Tailplane Aerodynamics and Aircraft Dynamics of the Ice Contaminated Tailplane Stall Phenomenon," Ph. D. Dissertation, Department of Aerospace, Aviation, and Applied Mechanics, The Ohio State University, Columbus, $\mathrm{OH}, 1998$. 


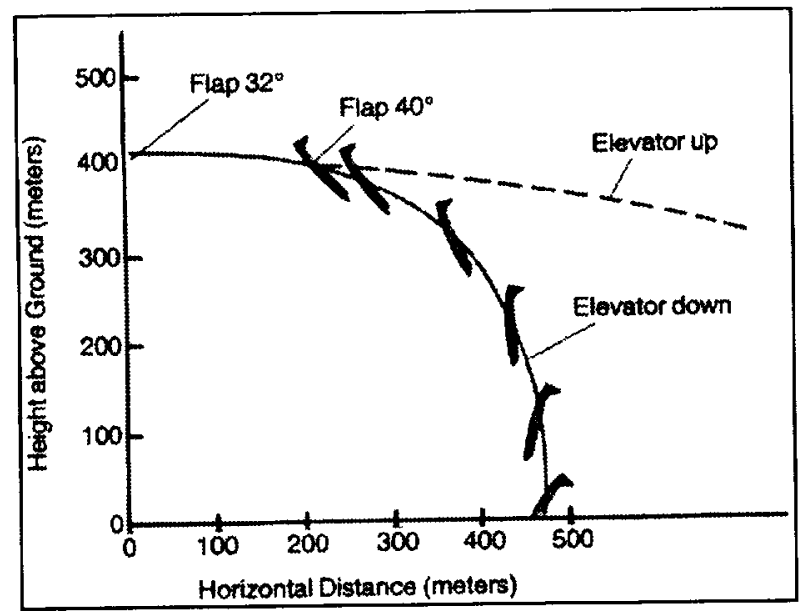

Figure 1 Trajectory of Vickers Viscount accident in Stockholm, Sweden 1977

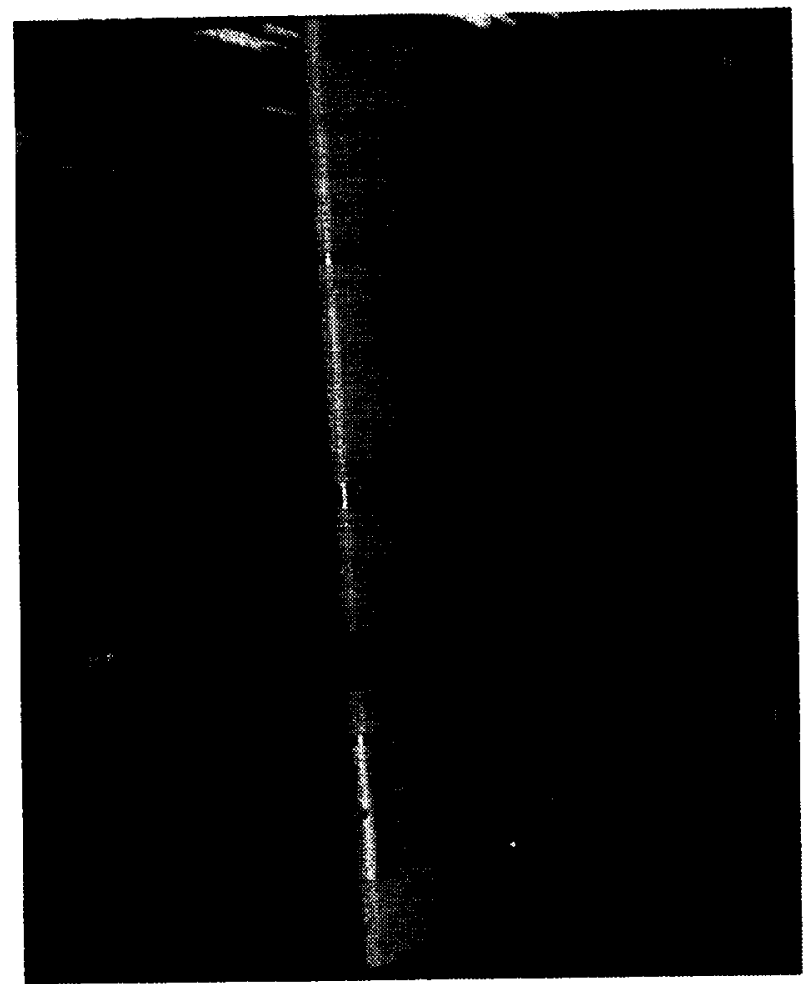

Figure 3 DHC-6 Tailplane model in OSU LSWT

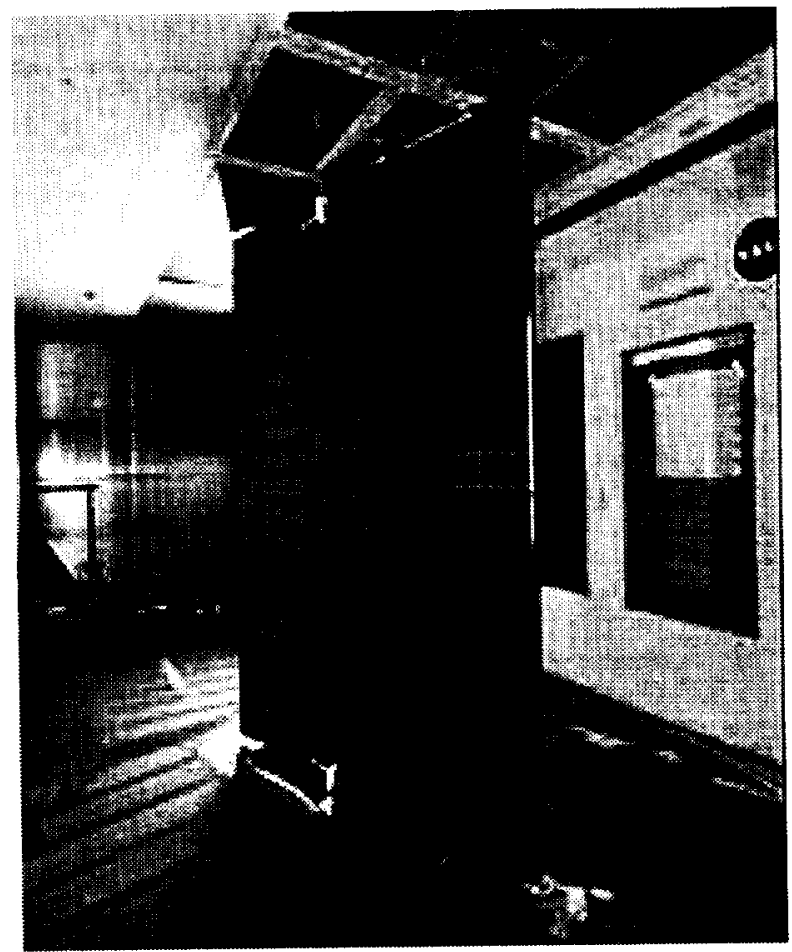

Figure 2 DHC-6 model in NASA IRT

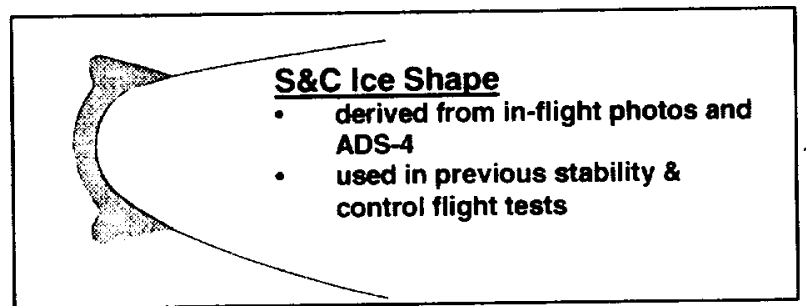

Figure 4 S\&C Ice Shape

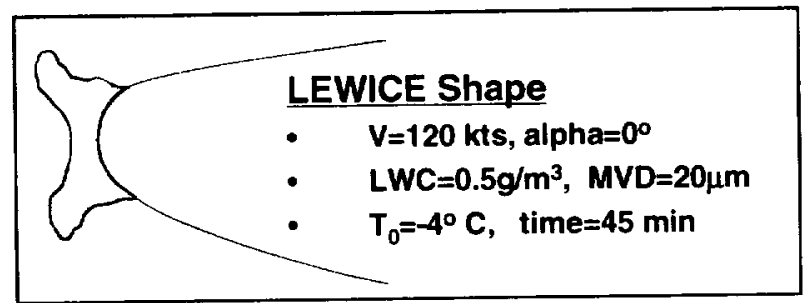

Figure 5 LEWICE Ice Shape 


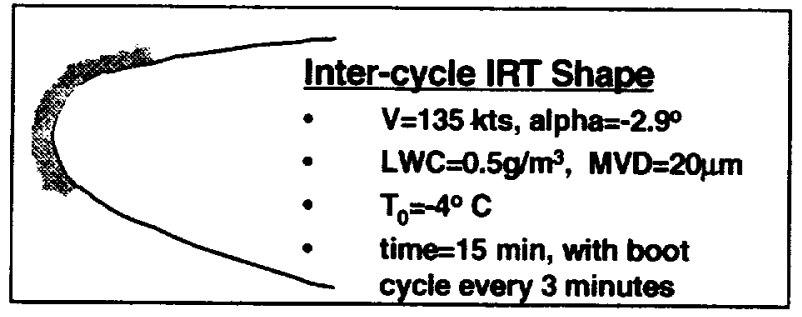

Figure 6 Inter-cycle IRT Ice

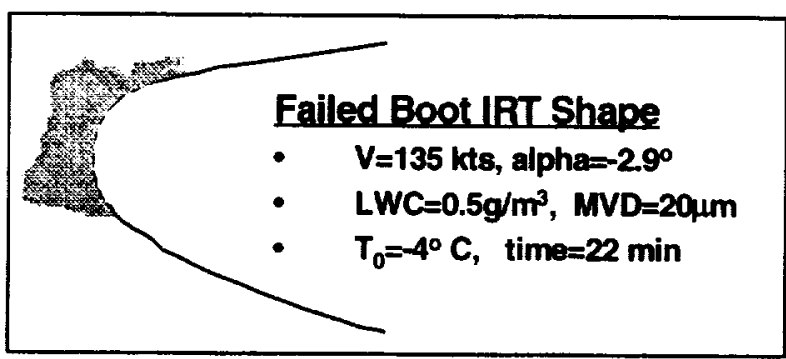

Figure 7 Failed Boot IRT Ice

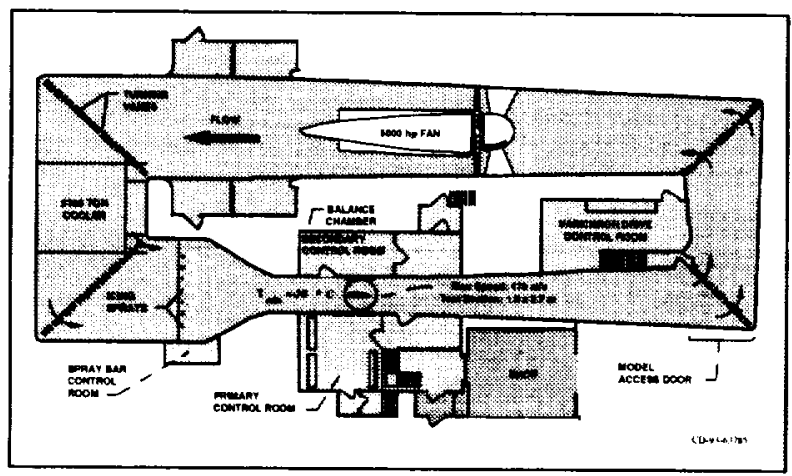

Figure 8 NASA Icing Research Tunnel

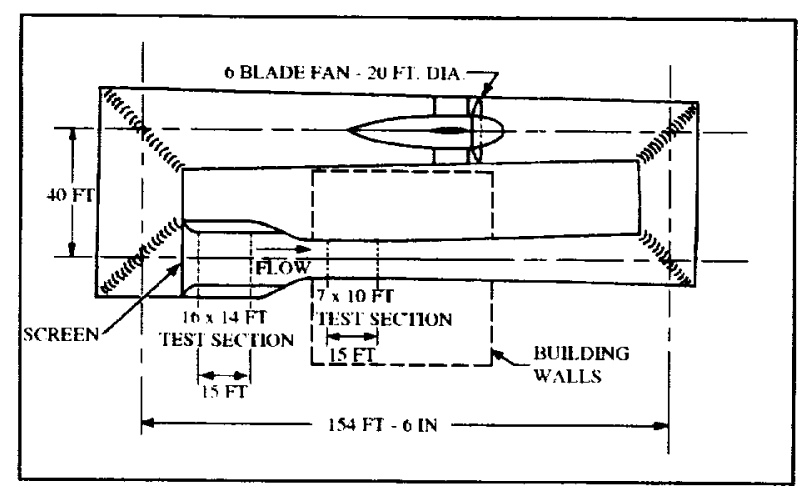

Figure 9 OSU 7'x 10' Low Speed Wind Tunnel

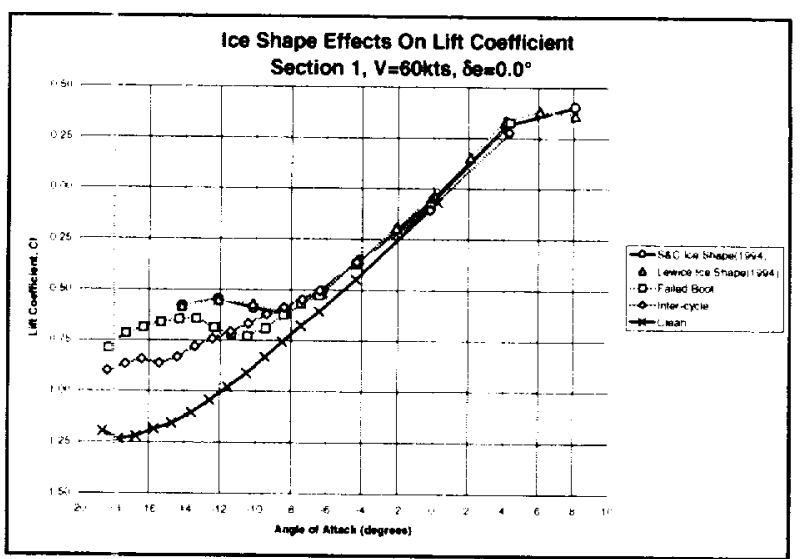

Figure $10 C_{l}$ Summary for all ice shapes

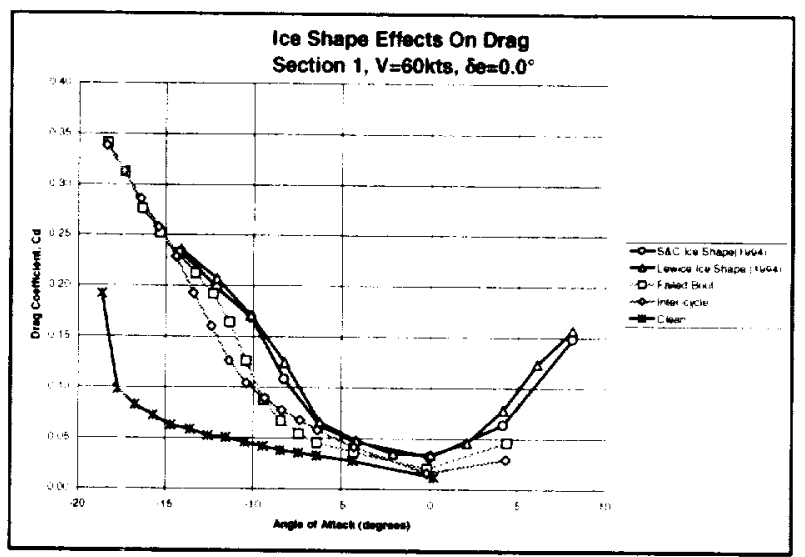

Figure $11 C_{d}$ data summary for all ice shapes

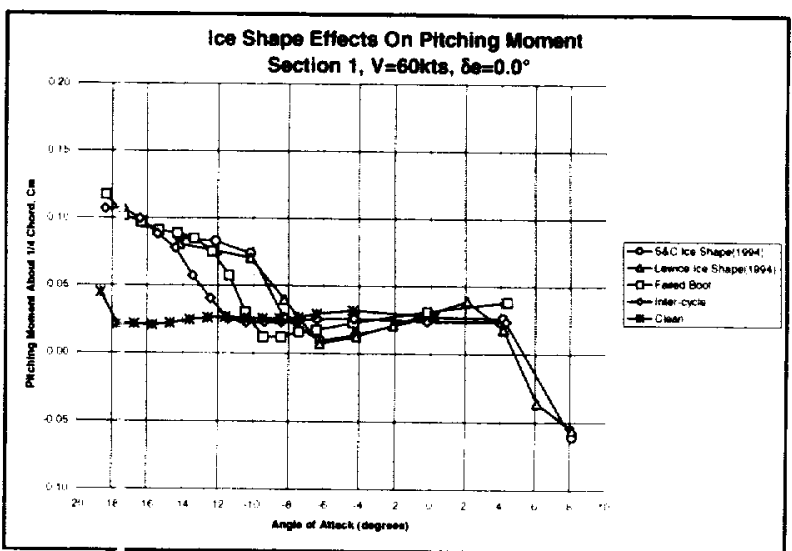

Figure $\mathbf{2} C_{m}$ Summary for all ice shapes 


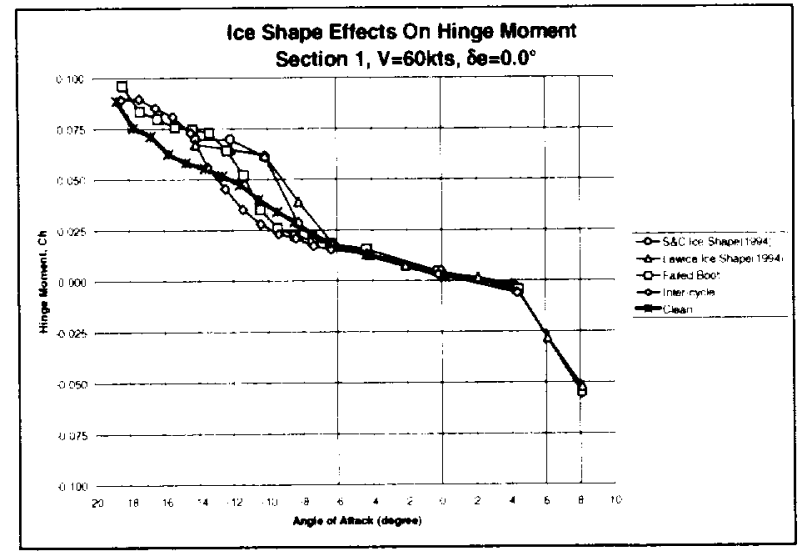

Figure $13 \mathrm{C}_{\mathrm{He}}$ Summary for all ice shapes

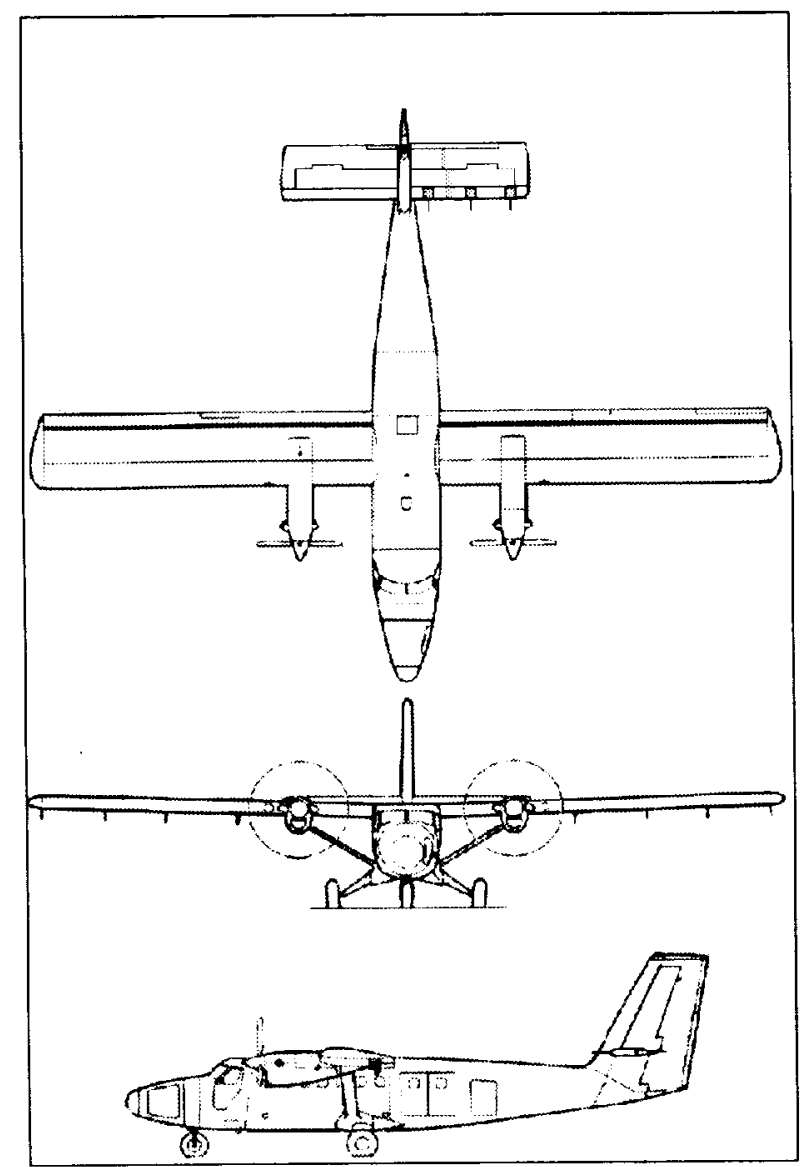

Figure 14 NASA Icing Research Aircraft with Tail Flow Probes

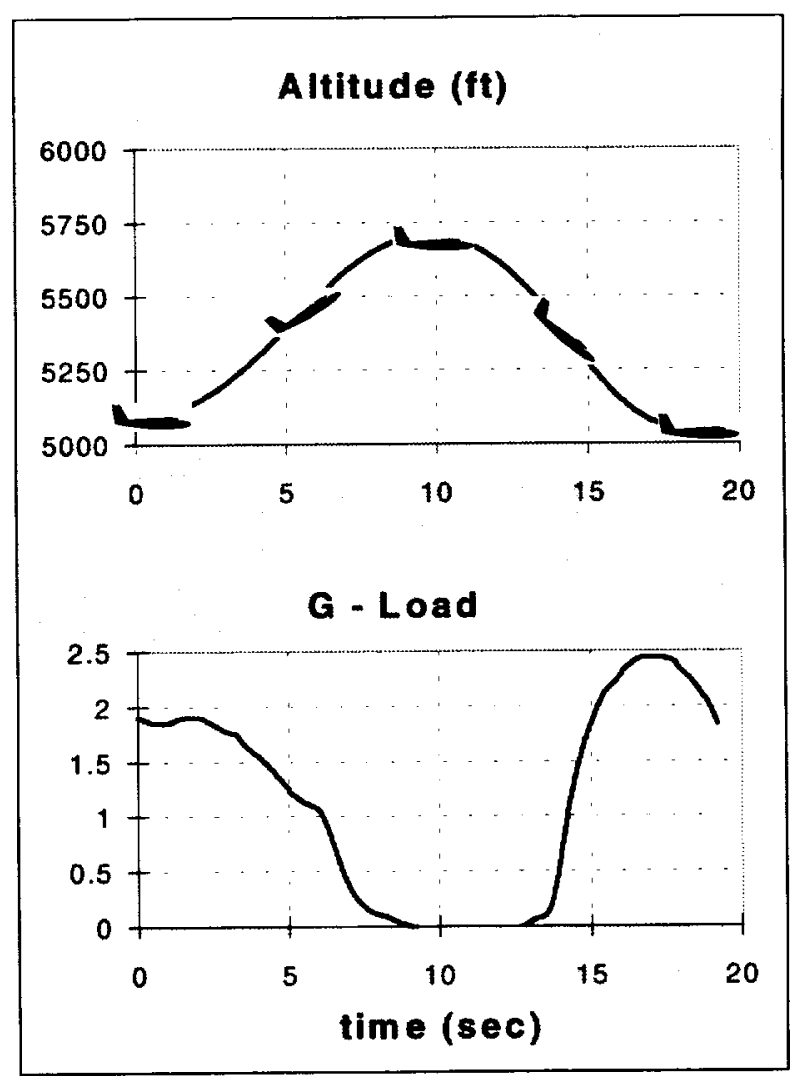

Figure 15 Zero-G Pushover Sample, $\delta \mathrm{F}=0, \mathrm{~V}=1.4 \mathrm{Vs}$

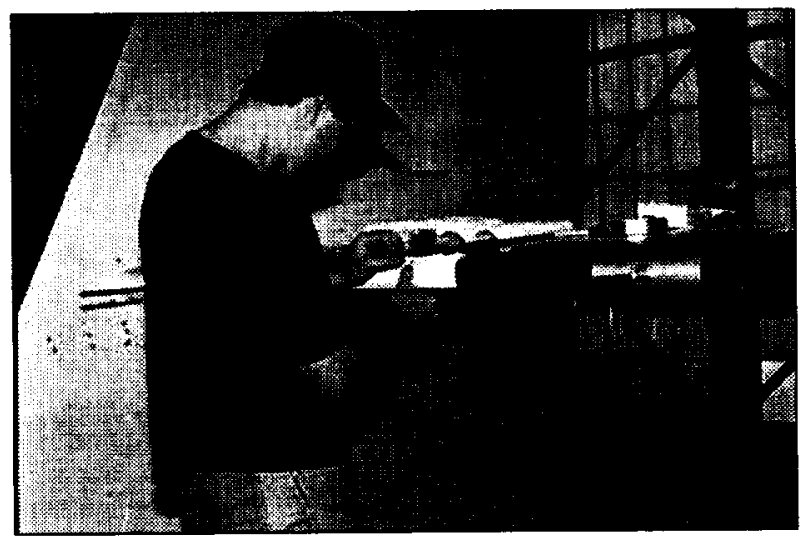

Figure 16 Installation of ice cast on tail 


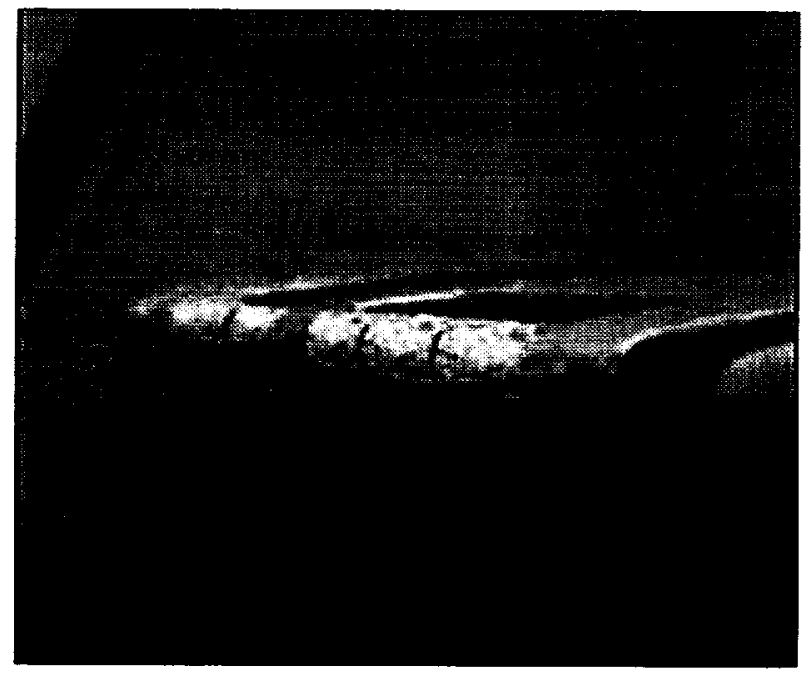

Figure 17 Inter-cycle Ice on Tailplane

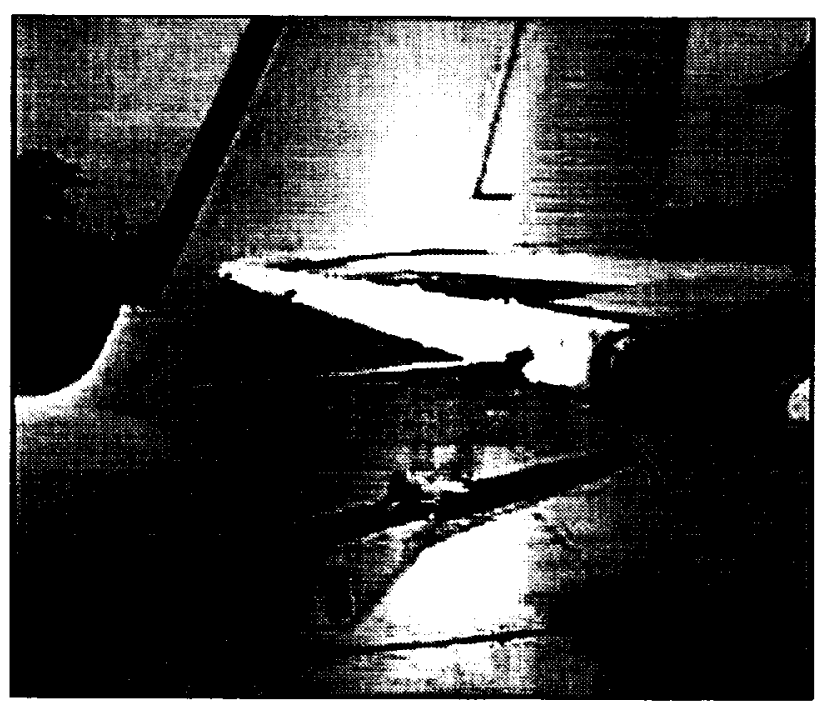

Figure 18 Failed Boot Ice on Tailplane

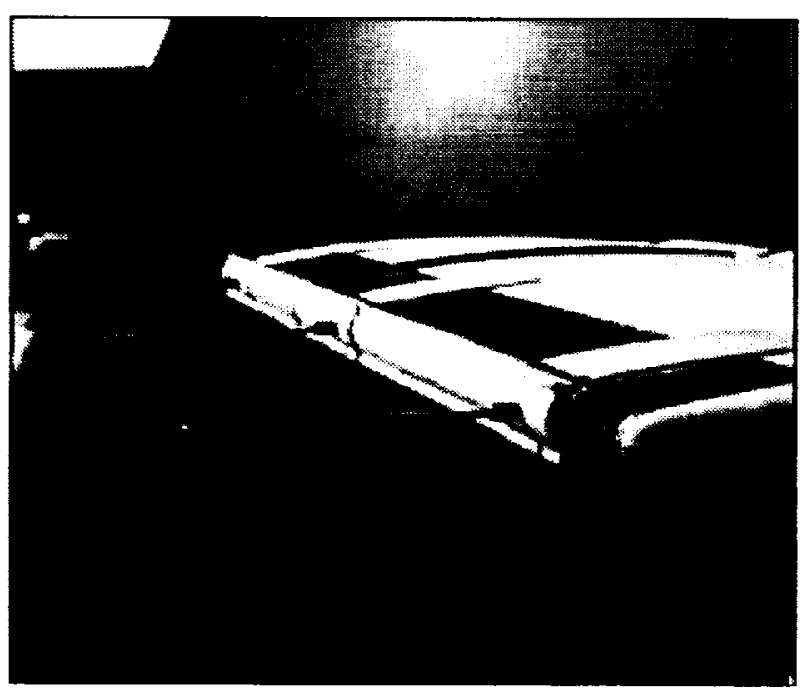

Figure 19 S\&C Ice on Tailplane
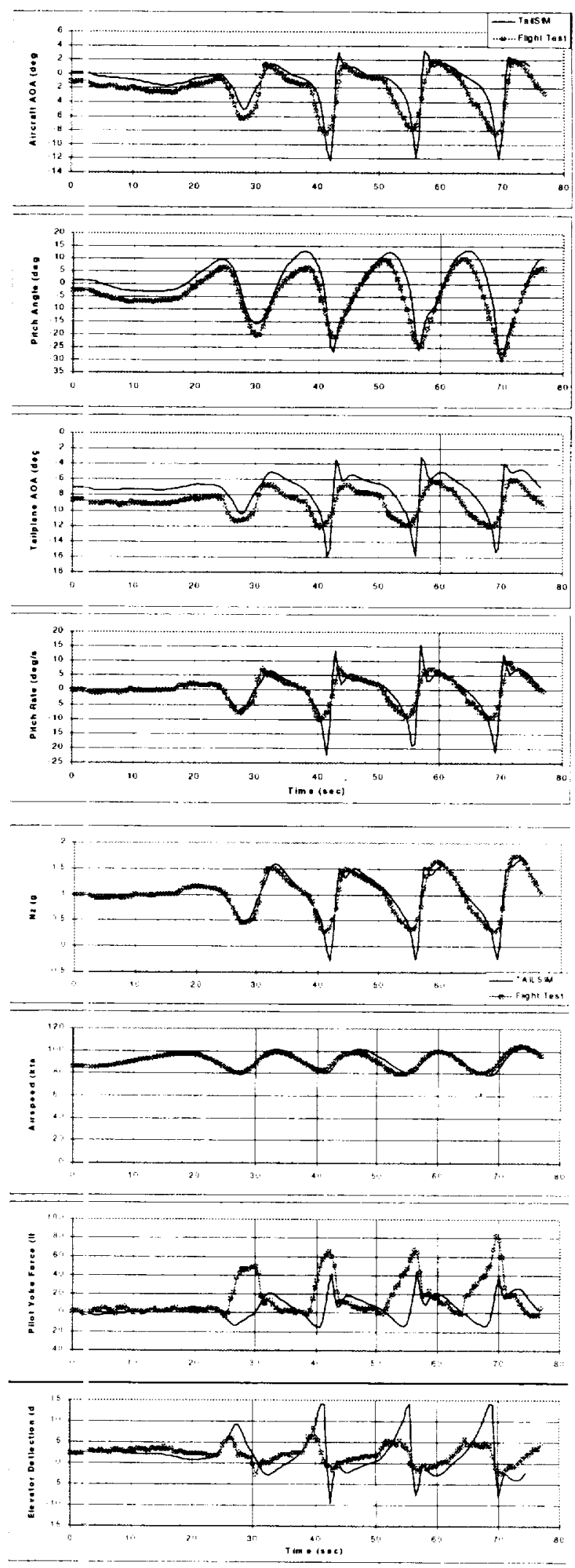

Figure 20 Comparison of TAILSIM to Flight Test for Pushover $\left(I c e=S \& C, \delta F=20, C_{T}=0.10\right.$ ) 

Public reporting burden for this collection of information is estimated to average 1 hour per response, inct iding the time for reviewing instructions, searching existing data sources. gathering and maintaining the data needed, and completing and reviewing the collection of information. Eend comments regarding this burden estimate or any other aspect of this collection of information, including suggestions for reducing this burden, to Washington Headquarters Sen ces. Directorate for information Operations and Reports. 1215 Jefferson Davis Highway, Suite 1204, Arlington. VA 22202-4302, and to the Oftice of Management and Budget, Pa serwork Reduction Project (0704-0188), Washington, DC 20503.

\begin{tabular}{l|l|l} 
1. AGENCY USE ONLY (Leave blank) & 2. REPORT DATE & 3. RE:POAT TYPE AND DATES COVERED
\end{tabular}

\begin{tabular}{|l|l|l} 
& January 1999 & Technical Memorandum \\
\hline 4. TITLE AND SUBTITLE
\end{tabular}

NASA/FAA Tailplane Icing Program Overview

6. AUTHOR(S)

WU-548-20-23-00

Thomas P. Ratvasky, Judith Foss Van Zante, and James T. Riley

7. PERFORMING ORGANIZATION NAME(S) AND ADDRESS(ES)

National Aeronautics and Space Administration

Lewis Research Center

Cleveland, Ohio 44135-3191

8. PERFORMING ORGANIZATION

REPORT NUMBER

E- 11502

9. SPONSORINGMONITORING AGENCY NAME(S) AND ADDRESS(ES)

10. SPONSORING/MONITORING AGENCY REPORT NUMBER

National Aeronautics and Space Administration

Washington, DC 20546-0001

NASA TM-1999-208901

AIAA-99-0370

\section{SUPPLEMENTARY NOTES}

Prepared for the 37th Aerospace Sciences Meeting \& Exhibit sponso ed by the American Institute of Aeronautics and Astronautics, Reno, Nevada, January 11-14, 1999. Thomas P. Ratvasxy, NASA Lewis Research Center; Judith Foss Van Zante. Dynacs Engineering Co.. Inc.. 2001 Aerospace Parkway, Brock Park, Ohio 44142 (work funded by NASA Contract NAS3-98008); James T. Riley, FAA Technical Center, Atlantic City Airport, New Jersey 08405. Responsible person, Thomas P. Ratvasky, organization code 5840, (216) 433-3905.

12a. DISTRIBUTION/AVAILABILITY STATEMENT 12b. DISTRIBUTION CODE

Unclassified - Unlimited

Subject Categories: 08, 03, and 05

Distribution: $\mathrm{N}$ snstandard

This publication is available from the NASA Center for AeroSpace Information, 1 301) 621-0390.

13. ABSTRACT (Maximum 200 words)

The effects of tailplane icing were investigated in a four-year NASA:FAA Tailplane Icing Program (TIP). This research program was developed to improve the understanding of iced tailplane aeroperformance and aircraft aerodynamics, and to develop design and training aides to help reduce the number of incidents and accidents caused by tailplane icing. To do this, the TIP was constructed with elements that included icing wind tunnel testing, dry-air aerodynamic wind tunnel testing. flight tests, and analytical code development. This paper pro $r$ ides an overview of the entire program demonstrating the interconnectivity of the program elements and reports on cur ent accomplishments.

14. SUBJECT TERMS

Aircraft icing: Stability and control; Tailplane icing: Tailplane perforı nance

\begin{tabular}{|c|c|}
\hline $\begin{array}{c}\text { 17. SECURITY CLASSIFICATION } \\
\text { OF REPORT } \\
\text { Unclassified }\end{array}$ & $\begin{array}{c}\text { 18. SECURITY CLASSIFICATION } \\
\text { OF THIS PAGE } \\
\text { Unclassified }\end{array}$ \\
\hline
\end{tabular}
19. SECU :ITY CLASSIFICATION OF AE STRACT Unclassified

